\title{
New records of the Lime Swallowtail Papilio demoleus Linnaeus, 1758 (Lepidoptera: Papilionidae) in Azerbaijan
}

\author{
Nigar Yusifova, László RÁKosY
}

Summary: Papilio demoleus LinNaEus, 1958 has been recorded for the first time in Azerbaijan. The larvae of the butterfly, are an important pest of citruses (Rutaceae).

Keywords: Lime Swallowtail, Papilio demoleus, Azerbaijan

\section{Introduction}

E. MÉNÉTRIÉs, collaborator of the Zoological Museum of Zoological Institute of the Russian Academy of Sciences (formerly Emperor's Museum), was the first entomologist engaged in studying butterflies in Azerbaijan (MÉNÉTRIÉs 1859). Later in the XIX century, J. LeDERER (1870a), O. STAUdinger (1861), and N.M. RoMANOFF (1884) carried out their investigations on butterflies in many districts of Azerbaijan, but especially in Talysh and Ordubad. During the Soviet period, the famous lepidopterologist M.A. RJABOv was engaged in studying lepidopterans of the Caucasus, including Azerbaijan (RJABOv 1958).

R.M. EFFENDI was among the first native entomologists who studied the butterfly fauna of Azerbaijan. EFFENDI reports on 223 butterfly species of Azerbaijan on the basis of his own field research and museum data (EFFENDI 1971). It is particularly worth mentioning Y.P. NeKrutenko (NeKRUTENKO 1990) and E. Dydmanidze's contributions (Dydmanidze 2004) in the research of butterflies of the Caucasus, including Azerbaijan.

According to the results of recent research, 248 species belonging to this group (i.e. Lepidoptera: Rhopalocera) are known to Azerbaijan (TsHIKOLOVETS and NeKRUtenko 2012).

Based on these species numbers and distribution information, it can be summarized that the butterfly fauna from Azerbaijan is insufficiently researched. This article reports for the the first record of the Lime Swallowtail Papilio demoleus LinNaEus, 1758 in Azerbaijan (Fig. 1).

\section{Geographical description of the investigated area in Azerbaijan}

Field work was carried out focusing on the Talysh area. It is located in the extreme south-eastern part of
Azerbaijan at the Caspian Sea, and to the west and south is bordered by the Republic of Iran . It stretches from the point where the sea shore region meets the steep ridge at $21 \mathrm{~m}$ b.s.l. up into the mountains at 2500 $\mathrm{m}$ a.s.l. The climate is damp and subtropical (SAFAROV 2013).

The region differs from the rest of the country by its numerous endemic species often representing relicts dating back to the Tertiary Period. By not having been affected by glaciation during the Pleistocene ice ages, these having been preserved here in the refuge of the tertiary forests under continuously favorable climatic conditions. Therefore, a State Reserve was established in 1936 in order to protect this highly relevant biodiversity and the unique landscape. In 2004, the State Reserve was transformed into Hirkan National Park with a total area of 21.435 ha (SAFAROV 2013). A part of the Hirkan National Park stretches in the Lankaran region (MAMMADOv et al. 2012).

However, thanks to its climatic and pedological conditions, the Talysh area is also highly suitable for fruit production. Mostly lemon (Citrus limon), feijoa (Acca sellowiana) and orange (Citrus aurantium) are grown in this territory.

\section{Results}

In the summer of 2018, the first author collected 5 male specimens of $P$. demoleus in the Lankaran district, Burjali village (N 38 $39^{\prime} 0^{\prime \prime}$, E $48^{\circ} 47^{\prime} 0^{\prime \prime}$ ) located in the south region of the Azerbaijan Republic (Fig. 2). The butterflies were flying in feijoa gardens (Acca sellowiana). Apart from 5 collected specimens, other specimens were observed flying or sucking nectar. The first specimen was observed and collected at 18.VII.2018 while sucking nectar on a flower of the bindweed Calystegia sepium (Convolvulaceae). The second specimen was observed and collected in feijoa gardens on 2.VIII.2018 (Fig. 3). 

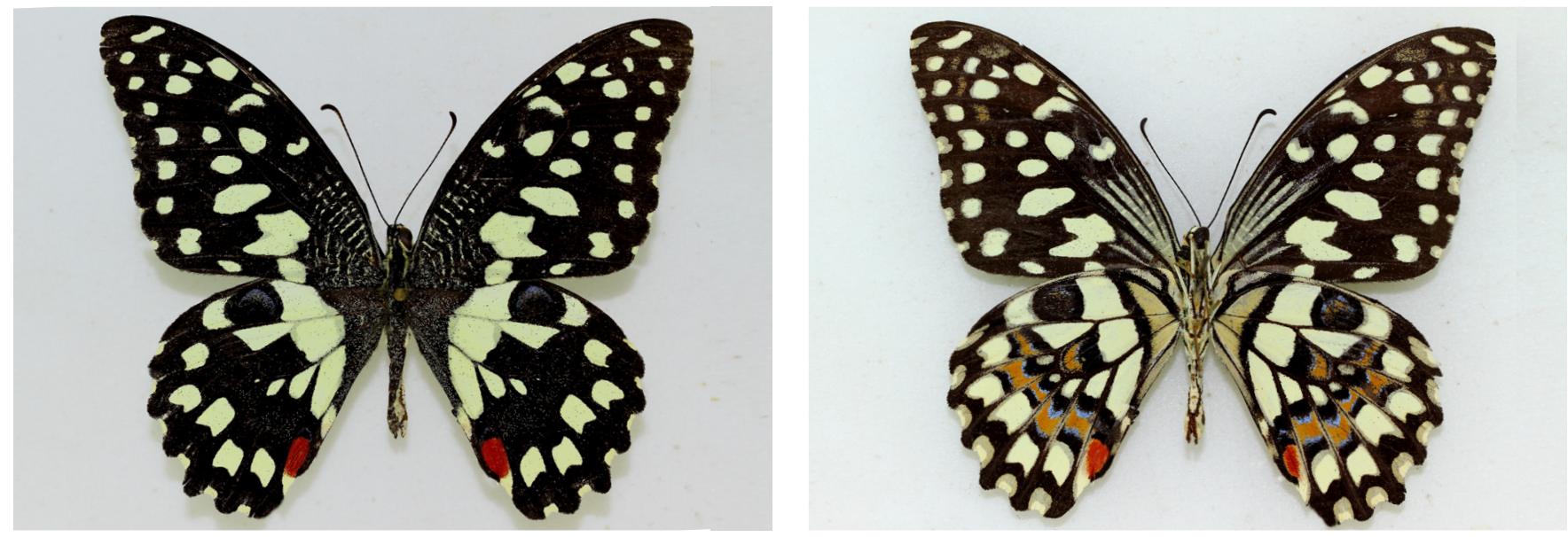

Fig. 1. Male specimen of Papilio demoleus LinnAEus, 1758 from Azerbaijan: dorsal (left), ventral (right).

\section{Discussion}

Papilio demoleus is a common and wide spread swallowtail butterfly. Being a pest and invasive species, it can be observed from Asia to Australia. The demoleus species group includs 5 monophyletic species (SMith and Vane-Wright 2010). Apart from $P$. demoleus, the most common and wide spread species of this group in Sub-Saharian Africa is $P$. demodocus. The remaining three species are particul restricted to Madagascar (ZAKHAROV et al. 2004a,b).

$P$. demoleus was observed and collected in and around citrus plantation and gardens. Thus, the habitat belongs to the extensive orchards, which are treated chemically several times a year. In Lankaran district, citrus orchards and nature reserves do not have natural margins and partly border each other in some parts of the region (Fig. 4).

\section{Biology and Ecology}

The preimaginal stages of $P$. demoleus have been well studied and documented. The egg is described e.g. by BADAWI (1981). The larval stages and biology were described by SHARIFI (1970). The moth can develop up to 6 generations a year (HEPPNER 2006, Homziak and Homziak 2006). The larvae of $P$. demoleus have 5 stadia.

The Lime Swallowtail is well known to be a serious Citrus pest, especially to young Lemon and Orange trees which may be completely defoliated by its large, voracious larvae (NARAYANAMMA et al. 2001). The high pest potential of the species is due to quick multiplying, and a whole life cycle is possible to be completed within 30 days in summer, if conditions are favourable. This reason evoked the Florida Department of Agriculture to issue a pest alert (HePPNer 2006) when P. demoleus was first observed in Puerto Rico (Homziak and HomziaK 2006).

Despite the fact that climate change may exert an increase of temperatures in the Eastern Mediterranean, it is unlikely that $P$. demoleus will be able to survive the colder and wetter winters that normally prevail

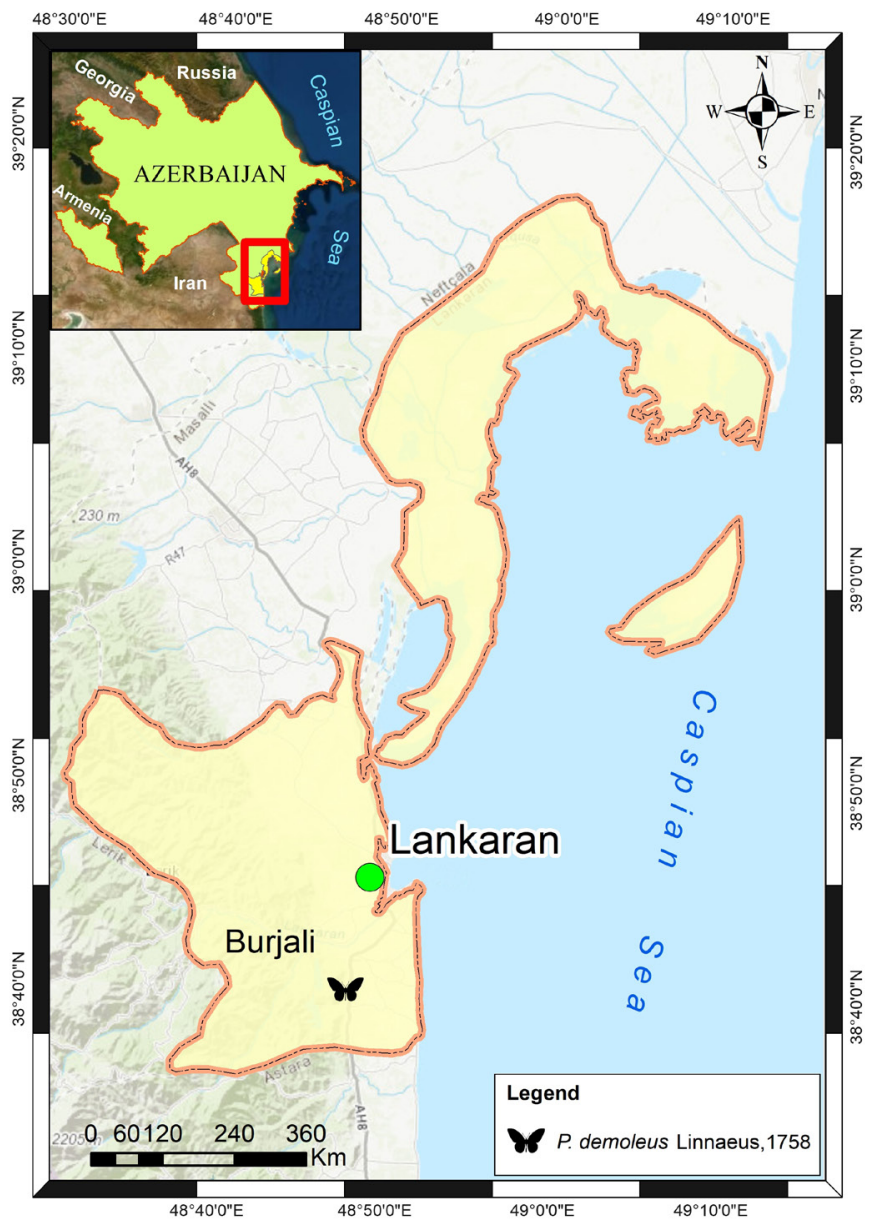

Fig. 2. First observations of Papilio demoleus in Azerbaijan

in the inland areas of the region. However, the more temperate coastal temperatures may allow the species to become established, and the $P$. demoleus group might even extend more to the west in forthcoming years (BENYAMINI et al. 2007).

\section{Distribution}

This species was found throughout tropical and subtropical regions of southern Asia (CORBET and Pendlebury 1992), Saudi Arabia (Badawi 1981), Iraq (LARSEN 1977), Iran (Sharifi and ZAREA 1970) 

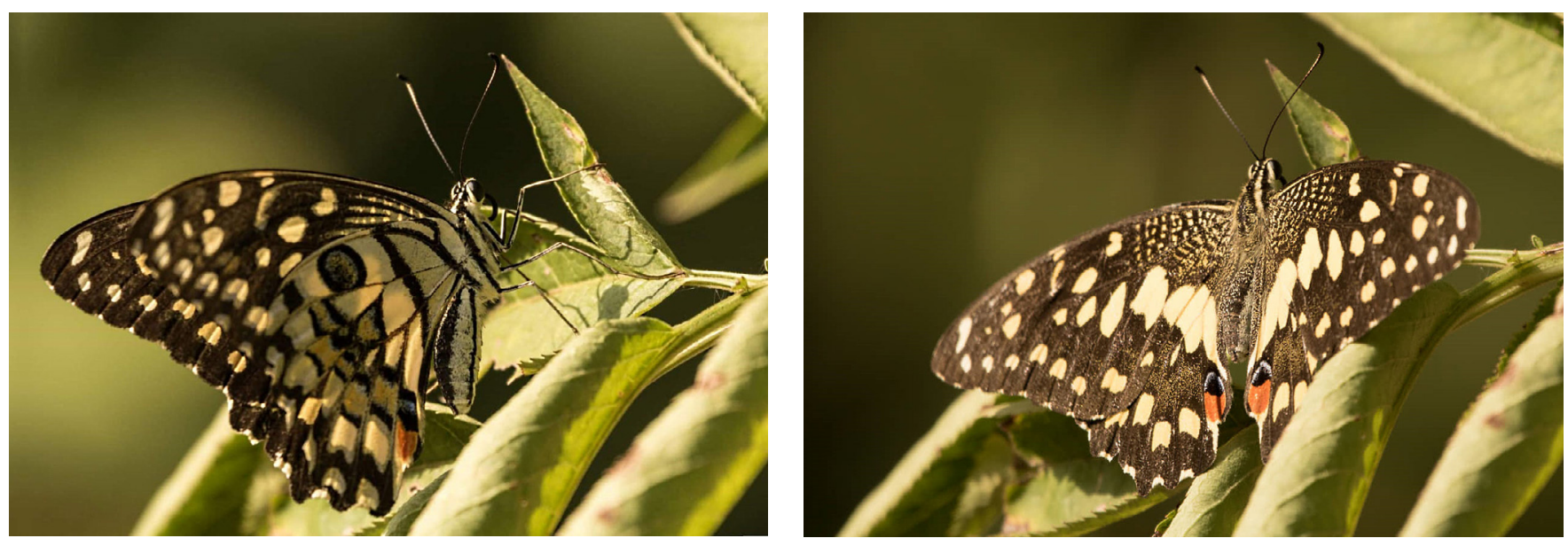

Fig. 3. Papilio demoleus LinnAEUs, 1758 from Lankaran district, Azerbaijan, photographed alive in nature, photos: IBRAHIMOV E.

and the Middle East to India, Nepal, southern China, Taiwan, and Japan (SARADA et al. 2013). In addition, it is observed in Cuba (RAYNER 2007), Malaysia, Indonesia (Kato 1989, Peggie et al. 2005), New Guinea (PARsons 1998) and Australia (Braby 2000).

Recently, Papilio demoleus has been recorded in the Dominican Republic (Guerrero et al. 2004), Puerto Rico (Homziak and Homziak 2006), and Carribbean (GARRAWAY et al. 2009).

In 2003 and 2004, P. demoleus was observed in such territories as central Syria, near Al Qaryatayn and Palmyra, and after a short period, in 2005, it was recorded in Turkey for the first time, in Nusaybin city (Mardin Province) close to the Syrian border (BENYAMinieT et al. 2007, KocaK et al. 2006, KocaK and AKDENIZ 2008).

Some specimens were collected from Ramsar (Iran) on $23^{\text {rd }}$ of July, in 2007 (LEHMANN and ZAHIRI 2011). This Oriental butterfly species, originally restricted in Iran to the southernmost regions of the country, was first introduced by men to the Teheran area and has spread there over the last two decades (NAZARI 2003). Anthropogenic impact on the current spread of $P$. demoleus was already suspected many times (SMith and Vane-Wright 2008). Presumably the species is $P$. demoleus from Iran, in South-East Azerbaijan after the year 2000 immigrated from Iran. Due to the good flight dynamics, the species will continue to spread north in the coming years.

\section{Acknowledgements}

The first author expresses her deep gratitude to the Ministry of Education of Romania and Ministry of Education of Azerbaijan (Governmental Scholarship Programme between Romania and Azerbaijan Republic) for the six-month scholarship at the Department of Taxonomy and Ecology of the Babeș-Bolyai University in Cluj.

We are thankful to Prof. Vladimir Lukhtanov for his helpful comments to improve the manuscript and $\mathrm{PhD}$ Hossein Rajaei for his information about distribution.

We are also thankful to Sheyda Maharramova (Institute of Zoology of ANAS) and Elman Yusifov, the director of

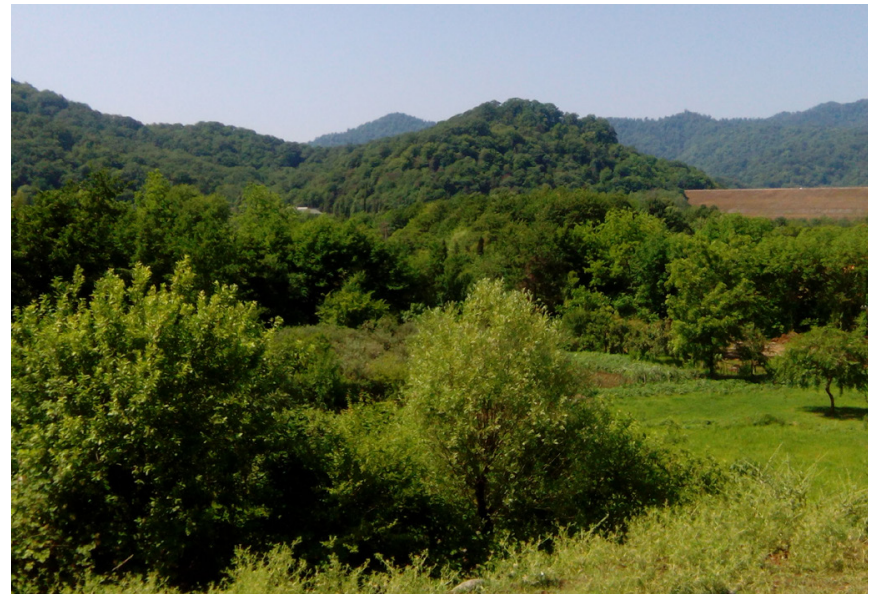

Fig. 4 . Citrus orchards in the Burjali Village, August 2018

the Institute of Zoology of National Academy of Sciences of Azerbaijan Republic, for their support in the organization of the field work in Lankaran district (Talysh).

Our sincerest thanks to the anonymous reviewers for constructive and insightful comments of our paper.

\section{References}

Ahmet K., Kemal M. and Akdeniz I. (2006) A new genus and species to the Lepidoptera Fauna of Turkey and Syria (Papilionidae). Centre for Entomological Studies Ankara 97: 1-6.

BADAWI A. (1981) Studies on some aspects of the biology and ecology of the citrus butterfly Papilio demoleus $\mathrm{L}$. in Saudi Arabia (Papilionidae, Lepidoptera). Zeitschrift für Angewandte Entomologie 91: 286-292.

Benyamini D., Bruschini C., Gianluca S. and Eddie J. (2007) First confirmed records of Papilio demoleus (LinNaEus 1758) in Syria, with comments on the species' appearance in Turkey and the Dominican Republic. News of the Israeli Lepidopterists Society 24 (2): 4-10.

BRABY M. (2000) Butterflies of Australia, their identification, biology, and distribution. CSIRO Publishing 2.

Corbet S. and Pendlebury M. (1992) The Butterflies of the Malay Peninsula. Malayan Nature Society $4^{\text {th }}$ edition.

DidMANIDZE E. (2004) Annotaed List of Diurnal Butterflies (Lepidoptera: Rhopalocera) of Georgia and adjacent territory from Southern Caucasus. Proceedings of the 
Institute of Zoology XXII: 197-226.

Eastwood R. and Boyce F. (2006) The Provenance of Old World Swallowtail Butterflies, Papilio demoleus (Lepidoptera: Papilionidae), Recently Discovered in the New World. Annals of the Entomological Society of America 99: 164-168.

EFFENDI R. (1971) Lepidoptera of Azerbaijan, their biology, ecology, zoogeography and agricultural importance (without families Noctuidae and Geometridae). Autoreferate of the Thesis of Candidate (Ph.D.) of Biological Sci. Degree. Baku. 31 pp. [In Russian]

Garraway E., Murphy C. and Allen G. (2009) Scientific Note: Papilio demoleus (the lime swallowtail) (Lepidoptera: Papilionidae), a potential pest of citrus, expanding its range in the Caribbean. Tropical Lepidoptera Research 19(1): 58-59.

Guerrero A.K., Denia V., Sarah L.B. and Brian D.F. (2004) First New World Documentation of an Old World Citrus Pest, the Lime Swallowtail Papilio demoleus (Lepidoptera: Papilionidae), in the Dominican Republic (Hispaniola). American Entomologist 50: 227-229.

HomziaK T. and HomziaK J. (2006) Papilio demoleus (Lepidoptera: Papilionidae): A new record for the united states, common wealth of Puerto Rico. Florida Entomologist 89 (4): 485-488.

Kato S. (1989) Notes on Papilio demoleus Linnaeus collected in Jawa, Indonesia (Lepidoptera, Papilionidae). Tyo to Ga 40: 189-191.

Kemal M. and Akdeniz D. (2008) On the Early Stages of Princeps demoleus (Linnaeus, 1758) in South East Turkey (Lepidoptera, Papilionidae). CESA News No.2.

LARSEN T. (1977) Extension recente en Iraq de l'aire de Papilio demoleus Linn. Entomops 42: 37-38.

LeDERER J. (1870a) Contributions à la faune des Lépidoptères de la Transcaucasie. Annales de la Société Entomologique de Belgique 13: 17-54.

LEHMANN L. and ZAHIRI R. (2011) Results of a lepidopterological expedition to North and Northwest Iran in summer 2007 with new records for Iran (Lepidoptera). Esperiana Band 16: 135-165.

Mammadov G., Yusifov E., Khalilov M. and Karimov V (2012) Azerbaijan: Ecotourism Potensial. EastWest Publishing House 1: p. 320.

MÉNÉTRIÉs E. (1859) Sur les lepidopteres de Lenkoran et de Talyche. Bulletin de la Classe physico-mathématique de l'Académie impériale des sciences de SaintPétersbourg 17: 313-316.

NAZARI V. (2003) Butterflies of Iran. Environmental Organization $564 \mathrm{p}$.

Nekrutenko Y. (1990) Diurnal Butterflies of Caucasus [in Russian].

PARSON M. (1998) The Butterflies of Papua New Guinea: their systematic and biology. Princeton University Press, Princeton, NJ.

Peggie D., Andrew R., and Vane-Wright R.I. (2005) An illustrated checklist of the papilionid butterflies
(Lepidoptera: Papilionidae) of northern and central Maluku, Indonesia. Nachr. ENTOMOL. Ver. Apollo, N. F. 26(1/2): 41-60.

Rayner N. (2007) Papilio demoleus Linnaeus, 1758 en Cuba (Lepidoptera: Papilionidae). Boletín Sociedad Entomológica Aragonesa 1(41): 440.

Rjabov M. (1958) Lepidoptera of Caucasus. Animal planet of USSR. Vol. 5, p. 351-375. [in Russian].

Romanoff N. (1884) Les Lepidopteres de la Transcaucasie. Memoires sur les Lepidopteres 1: 1-92, pl. 1-5.

Safarov H. (2009) Rare and Endangered Plant Species in Hirkan National Park and its Environs. 2009. Status and Protection of Globally Threatened Species in the Caucasus. Tbilisi: CEPF, WWF. Contour Ltd., 232 pp.

Safarov H. (2013) The Main Edificators of Hyrcanian Type Forests in the South of the Azerbaijan Republic. International Caucasian Forestry Symposium. Turkey, Artvin p.605-610.

Sarada G., Gopal K., Venkata Ramana K.T., Mukunda Lakshmi L. and Nagalakshmi T. (2013) Citrus Butterfly (Papilio demoleus Linnaeus) Biology and Management: A Review. Research and Reviews: Journal of Agriculture and Allied Sciences 3 (1): 17-25.

SHARIFI S. and ZAREA N. (1970) Biology of the Citrus Butterfly, Papilio demoleus demoleus (Lepidoptera: Papilionidae). Annals of the Entomological Society of America 63 (5): 1211-1213.

SheYla Y., Rolando T. and DaYron B. (2018) Occurrence of the Lime Swallowtail Papilio demoleus Linnaeus, 1758 (Lepidoptera: Papilionidae) in Western Cuba. Ecologica Montenegrina 18: 15-17.

Smith C.R. and VAne-Wright R.I. (2008) Classification, nomenclature and identification of lime swallowtail butterflies: a post-cladistic analysis (Lepidoptera: Papilionidae). Systematics and Biodiversity 6: 175-203.

STAudinger O. (1861) Catalog der Lepidopteren Europa's und der angrenzenden Länder. Dresden. 192 S.

Tshikolovets V. and Nekrutenko Y. (2012) The Butterflies of Caucasus and Transcaucasia (Armenia, Azerbaijan, Georgia and Russian Federation). Kyiv Pardubice. Tshikolovets Publications, p. 423.

Wiemers M. (2012) First record of the Lime Swallowtail Papilio demoleus LinnaEus, 1758 (Lepidoptera, Papilionidae) in Europe. The Journal of research on the Lepidoptera. The Journal of Research on the Lepidoptera 45: 85-89.

Zakharov E., Cateriono M. and Sperling F. (2004a) Molecular phylogeny, historical biogeography, and divergence time estimates for swallowtail butterflies of the genus Papilio (Lepidoptera: Papilionidae). Systematic Biology 53(2): 193-215.

Zakharov E., Smith C., Lees D., Cameron A., VaneWright R.I. and SPERLING F. (2004b) Independent gene phylogenies and morphology demonstrate a Malagasy origin for a wide-ranging group of Swallowtail butterflies. Evolution 58 (12): 2763-2782.
Nigar Yusifova
Azerbaijan National Academy of
Sciences, Institute of Zoology
24 Istiglaliyyat Street, Baku, Azerbaijan
E-mail: n.yusifova@zoology.science.az

László RÁKOSY

Department of Taxonomy and Ecology Babeș-Bolyai University, Clinicilor 5-7 Cluj-Napoca, 400006, Romania

E-mail: laszlo.rakosy@ubbcluj.ro
Received: 30.11.2019

Accepted: 15.12.2019

Published online: 31.12.2019

Published: 31.12 .2019

Online article number: ER23201903

doi: 10.24193/entomolrom.23.3 